\title{
New Therapeutic Options for Breast Cancer during Pregnancy
}

\author{
Sibylle Loibl \\ German Breast Group Forschungs GmbH, Neu-Isenburg, Germany
}

\section{Key Words \\ Breast cancer · Pregnancy · Chemotherapy · Radiation}

\section{Summary}

National and international guidelines for pregnant breast cancer patients recommend to treat pregnant patients as closely as possible to the standards for non-pregnant patients. Therefore, new treatment options like sentinel lymph node biopsy or taxane-based chemotherapy have to be carefully checked for their possible implementation even for pregnant patients. These patients need to be treated in a breast cancer center where a multidisciplinary team is ready to support the patient and her family and to serve her with the best up-to-date treatment for mother and child.

\section{Introduction}

Pregnancy-associated breast cancer (PABC) is defined as breast cancer diagnosed during pregnancy and within 1 year of delivery. The present article deals mainly with the situation of coinciding breast cancer and pregnancy. The age of the mother at delivery has been increasing in the last 30 years, and is approximately 30 years on average in Germany. Breast cancer is rare in young patients. Women below the age of 40 represent less than $10 \%$ of patients who develop breast cancer; still, breast cancer is not uncommon in young women. In Western countries, breast cancer is the most common cause of cancer deaths in women aged 30 years. Presently, 1 in 3,000 to 1 in
Schlüsselwörter

Mammakarzinom - Schwangerschaft - Chemotherapie . Radiotherapie

\section{Zusammenfassung}

Nationale und internationale Behandlungsrichtlinien für Patientinnen mit Mammakarzinom in der Schwangerschaft empfehlen heute eine Therapie so nah wie möglich am Standard für nicht schwangere Mammakarzinompatienten. Neue Therapieoptionen wie die SentinelNode-Biopsie oder die Taxane sollten daher genau geprüft werden, um sie in die Therapie auch für Schwangere integrieren zu können. Die Patientinnen sollten in einem Brustkrebs-Zentrum behandelt werden, wo ein interdisziplinäres Team der Frau und ihren Angehörigen zur Seite steht und die bestmögliche Therapie für Mutter und Kind zur Verfügung stellen kann.

10,000 pregnancies is complicated by breast cancer, but with the trend to postponing pregnancy, an increased rate of breast cancers during pregnancy is likely.

\section{Presentation and Diagnosis}

Although the majority of breast masses found during pregnancy will not be malignant, a clinically suspicious or persistent breast and/or axillary mass should be imaged and biopsied, especially if imaging fails to confirm a benign etiology of the mass. There is only limited data on the use of breast diagnostic imaging procedures during pregnancy $[1,2]$. With ade-

\begin{tabular}{|c|c|}
\hline KARGER & (C) 2008 S. Karger GmbH, Freiburg \\
\hline $\begin{array}{l}\text { Fax }+497614520714 \\
\text { E-mail Information@Karger.de } \\
\text { www.karger.com }\end{array}$ & $\begin{array}{l}\text { Accessible online at: } \\
\text { www.karger.com/brc }\end{array}$ \\
\hline
\end{tabular}


quate abdominal shielding, mammography presents little risk to the fetus. A dose of $200-400 \mathrm{mGy}$ is delivered by standard bilateral mammography using modern technology. That would result in less than $50 \mathrm{mrad}(500 \mu \mathrm{Gy})$ exposure to the embryo/fetus, well below the level of $10 \mathrm{rad}(100 \mathrm{mGy})$ that increases the risk of fetal malformations by $1 \%$ [3]. This is less than the estimated environmental exposure of $2 \mathrm{mGy}$ per week. Although the reports on the utility of breast and nodal basin ultrasound are limited, this modality may be of benefit in the evaluation of a breast mass and should pose no harm to the developing fetus [4]. Because of a lack of data demonstrating its efficacy, the concern over the safety of gadolinium and the difficulty of positioning of the pregnant patient on her stomach, we do not recommend magnetic resonance imaging (MRI) in the diagnosis of breast cancer during pregnancy.

\section{Biological Characteristics of Breast Cancer in Pregnancy}

The pathologic features of breast cancer diagnosed during pregnancy have been analyzed in numerous studies. Due to the retrospective nature of such studies and the paucity of case control studies it is impossible to directly compare the biological properties of breast cancer in pregnant and in nonpregnant patients of similar age. The vast majority of breast cancers are invasive ductal [5]. It is likely that in addition to larger tumor diameters and more frequent involvement of the regional lymph nodes, breast cancers in pregnancy are characterized by poor differentiation and low expression of estrogen and progesterone receptors [6-11]. A recent review identified 13 studies reporting estrogen receptors in breast cancer diagnosed during pregnancy; estrogen receptors were negative in 138 of 235 patients $(59 \%, 95 \%$ confidence interval $52-65 \%)$ [12]. The proportion of breast cancers with overexpression of HER-2 protein was similar in pregnant and in young nonpregnant patients [13-15]. Given the known unfavorable characteristics, breast cancer in pregnancy has been regarded as particularly aggressive. Some case control studies do indeed report an elevated risk of breast cancer death in patients diagnosed during pregnancy. However, the majority of case control studies with multivariate statistical analysis of prognostic and predictive factors, failed to identify pregnancy as an independent negative prognosticator of the outcome of breast cancer. A more extensive review has been published by Barthelmes et al. [16].

\section{Local Therapy}

\section{Surgery}

Breast surgery can be safely performed during all trimesters of pregnancy with minimal risk to the developing fetus $[17,18]$. It may be advisable to wait until the 12 th week of gestation has been completed because the risk of a spontaneous miscarriage is highest before the 12th week of gestation. During surgery, monitoring of the fetus should take place.

Breast-conserving surgery with axillary lymph node dissection is possible [19,20], although in most published reports, the majority of pregnant patients have had mastectomies, most likely because of concerns over radiation during pregnancy, the stage at presentation, and patterns of practice [21, 22].

Sentinel lymph node (SLN) biopsy has not been systematically evaluated in the pregnant patient with breast cancer. The estimated dose of radiation to the fetus through the use of technetium has been estimated to be low, and pregnant patients could be offered SLN biopsy after counseling regarding the amounts of radiation involved [23,24]. The estimated fetal dose is probably negligible and is much less than the limit of $1 \mathrm{mSv}$ over the gestation period for a declared pregnant woman. Therefore, using standard techniques, lymphoscintigraphy with $99 \mathrm{mTc}$-sulfur colloid for SLN mapping can be safely applied during pregnancy, as estimated fetal doses are not associated with significantly increased risk to the fetus. Isosulfan blue dye mapping is not recommended in pregnant patients because it has not been approved, and anaphylaxis has been observed with the use of this dye [25, 26]. However, given that the majority of patients have clinical lymph node involvement at the time of primary diagnosis, most pregnant women with breast cancer do not qualify for SLN anyway.

\section{Radiation Therapy}

Adjuvant radiation therapy exposes the fetus to ionizing radiation. The absorbed dose depends on the gestational age and the position of the fetus [27]. Whether or not detrimental effects of adjuvant radiation therapy are to be anticipated, is still a matter of debate $[2,28]$. However, the start of adjuvant radiation therapy is never urgent; delays of radiation therapy of up to 3-4 months result in similar outcomes as earlier initiation [29-31].

\section{Systemic Adjuvant Therapy}

\section{Endocrine Therapy}

Adjuvant hormonal therapy is not indicated in pregnancy as the initiation of hormonal therapy is never an emergency. Hormone treatment, if indicated, is to be started after delivery and after completion of chemotherapy.

\section{Chemotherapy}

The indications for adjuvant chemotherapy in pregnant patients are identical to those in non-pregnant patients. Thus, preoperative (neoadjuvant) chemotherapy may be indicated for the therapy of locally advanced breast cancer according to recent consensus guidelines [32].

The timing of chemotherapy is crucial: While it is obviously preferable to postpone chemotherapy until after delivery, this 
Table 1. Taxanes during pregnancy

\begin{tabular}{|c|c|c|c|c|c|c|c|}
\hline $\begin{array}{l}\text { Age, } \\
\text { years }\end{array}$ & Therapy & $\begin{array}{l}\text { Start, } \\
\text { week }\end{array}$ & $\begin{array}{l}\text { Delivery, } \\
\text { week }\end{array}$ & Tumor & Weight, g & Complications & $\begin{array}{l}\text { Follow up, } \\
\text { months }\end{array}$ \\
\hline $30-42$ & paclitaxel & $17-30$ & $32-38$ & $\begin{array}{l}\mathrm{OC}(\times 6) \\
\mathrm{BC}(\times 4) \\
\mathrm{CC}(\times 1)\end{array}$ & $1460-2800$ & $\begin{array}{l}\text { preeclampsia } \\
\text { fetal distress } \\
\text { preterm rupture of the membrane }\end{array}$ & $3-36$ \\
\hline $28-44$ & docetaxel & $14-32$ & $32-40$ & $\mathrm{BC}(\times 6)$ & $1620-3080$ & hydrocephalus & $9-28$ \\
\hline
\end{tabular}

$\mathrm{BC}=$ Breast cancer $; \mathrm{OC}=$ ovarian cancer $; \mathrm{CC}=$ cervical cancer.

is not always possible. For instance, locally advanced tumors may need to be treated in a neoadjuvant concept. In addition, for patients whose tumors do not express estrogen receptors, the late start of chemotherapy, i.e. > 3 weeks after surgery, may worsen the prognosis dramatically as compared to an early start of chemotherapy [33]. The efficacy of very late adjuvant chemotherapies, e.g. starting later than 8 weeks after surgery, is unknown. Thus, chemotherapy may need to be started during pregnancy even in patients with estrogen receptor-positive tumors. Chemotherapy is contraindicated in the first trimester of pregnancy as the fetus is undergoing organogenesis and is vulnerable to the teratogenic effects of chemotherapy [34]. If chemotherapy cannot be postponed to the second trimester of pregnancy, abortion is indicated. Abortion by itself has never been proven to have a beneficial therapeutic effect in breast cancer [35]. In the second and third trimester, chemotherapy is relatively safe as illustrated by the most recent series of patients reported by investigators from the M.D. Anderson Cancer Center [36] and from the Royal Marsden Hospital [37].

The Royal Marsden series consists of 28 women [38]. This series is characterized by a heterogenous use of chemotherapy; as in other case series, the use of chemotherapy in the 2nd and 3rd trimester was safe. Methotrexate is an abortifacient, and has been reported to cause severe fetal malformations when given in the first trimester [4]. It is not of particular importance in the contemporary management of breast cancer. It has been recommended, thus, that methotrexate be avoided during pregnancy. The largest well-characterized case series of patients with breast cancer in pregnancy was updated recently by investigators from the M.D. Anderson Cancer Center [36]. All patients were treated with FAC (5-fluorouracil: $500 \mathrm{mg} / \mathrm{m}^{2}$ days 1-4; adriamycin: $50 \mathrm{mg} / \mathrm{m}^{2}$ continuous 72 -h days $1-3$; cyclophosphamide: $500 \mathrm{mg} / \mathrm{m}^{2}$ day 1 of a 3 -week cycle) during the 2nd and 3rd trimester of pregnancy. Both case series report favorable fetal short-term as well as long-term outcomes with no reason to suspect an increased risk of malformations and permanent side effects. Similar results have been reported in a case collection of Canadian patients reported by the Toronto group [37] and in a systematic review of the literature [39].

In recent years, taxanes (paclitaxel and docetaxel) have become important components of adjuvant therapy [40-42].
Their use in pregnancy has been reported in a small number of patients with breast [43-46] and other neoplasias [47] (table 1). So far, there is no evidence of a detrimental effect of taxane use after the 1st trimester. There are pharmacological data postulating that vincaalcaloids and paclitaxel can be safely administered during pregnancy because these tubulinbinding agents can be bound by drug-extruding transporters of the placenta, such as P-glycoprotein $(\mathrm{PgP})$ or breast cancer resistance protein 1 (BCRP-1), which are highly expressed in the placenta $[48,49]$. Fetal drug exposure increases dramatically by absence or pharmacological blocking of placental $\mathrm{PgP}$.

\section{Trastuzumab and Other Targeted Therapies}

Trastuzumab is an effective adjuvant therapy in patients with HER-2 amplified breast cancer. It has been investigated in randomized trials in parallel to sequential taxanes [50,51] and after the completion of chemotherapy [52] with similar efficacy at 1 or 2 years of follow-up. Trastuzumab is known to cross the placenta in primate models; it is labeled as a category B drug in the United States, as no harm has been observed in monkeys. It has been used in very few pregnant patients to treat early [53] and metastatic breast cancer [54, 55]. Whereas no malformations or fetal intrauterine deaths were described, 3 fetuses developed reversible oligohydramnios, 2 anhydramnios, and 1 infant died postpartum [55]. Whether or not this was a consequence of intrauterine heart failure is not known. Only in 2 cases, no fetal complications were detected (table 2). At the present time, it seems prudent to consider the efficacy of the sequential use of chemotherapy and trastuzumab and to defer the adjuvant therapy with trastuzumab to the postpartum period. Lapatinib was used inadvertently in 1 pregnant patient: no adverse outcome was observed [56]. For trastzumab the same considerations apply in advanced and in early breast cancer. We are not aware of a report of bevacizumab during pregnancy. Based on the experience of thalidomide, however, it is obvious that antiangiogenic agents may have catastrophic consequences when used during early pregnancy.

\section{Supportive Care}

Antiemetics such as short-term glucocorticosteroids and most serotonin receptor III antagonists are considered safe in preg- 
Table 2. Overview of biological treatment during pregnancy

\begin{tabular}{|c|c|c|c|c|c|c|c|c|}
\hline Author & $\begin{array}{l}\text { Age, } \\
\text { years }\end{array}$ & Therapy & $\begin{array}{l}\text { Exposure, weeks } \\
\text { of gestation }\end{array}$ & $\begin{array}{l}\text { Delivery, } \\
\text { week/mode }\end{array}$ & Breast cancer & $\begin{array}{l}\text { Pregnancy } \\
\text { complications }\end{array}$ & $\begin{array}{l}\text { Birth } \\
\text { weight, g }\end{array}$ & Neonatal status \\
\hline Fanale 2005 [54] & 26 & $\begin{array}{l}\text { vinorelbine } 25 \mathrm{mg} / \mathrm{m}^{2} \\
\text { weekly + trastuzumab } \\
\text { weekly ( } 1 \text { cycle), } \\
\text { further postpartum }\end{array}$ & $\begin{array}{r}27-34.50 \\
(1 \text { cycle })\end{array}$ & $34+5 /$ vaginal & $\begin{array}{l}\text { liver } \\
\text { metastases }\end{array}$ & $\begin{array}{l}\text { oligohydramnios; } \\
\text { occasional fetal } \\
\text { cardiac } \\
\text { decelerations }\end{array}$ & 2,270 & $\begin{array}{l}\text { male; no sequelae; } \\
\text { status } \\
\text { APGAR 9/9/- }\end{array}$ \\
\hline Watson 2005 [59] & 28 & $\begin{array}{l}\text { trastuzumab } 580 \mathrm{mg} \\
3 \text { weekly } \\
\text { over } 5 \text { months, } \\
\text { then STOP }\end{array}$ & $0-23$ (7 cycles) & $37+3 /$ vaginal & primary & $\begin{array}{l}\text { reversible } \\
\text { anhydramnios } \\
\text { at } 23 \text { weeks }\end{array}$ & 2,960 & $\begin{array}{l}\text { female; no sequelae; } \\
\text { status APGAR 8/9/- }\end{array}$ \\
\hline $\begin{array}{l}\text { Waterston and } \\
\text { Graham } 2006 \text { [60] }\end{array}$ & 30 & $\begin{array}{l}\text { trastuzumab } 736 \mathrm{mg} \\
\text { loading, } 523 \mathrm{mg} \\
2 \text { cycles, then STOP }\end{array}$ & $\begin{array}{l}\text { before conception, } \\
\text { after } 2 \text {.cycle } \mathrm{T} \\
\text { pregnant }\end{array}$ & $\begin{array}{l}\text { week of delivery } \\
\text { not reported/ } \\
\text { vaginal }\end{array}$ & primary & none & $\begin{array}{l}\text { not } \\
\text { reported }\end{array}$ & $\begin{array}{l}\text { female; no sequelae; } \\
\text { status APGAR } \\
\text { not reported }\end{array}$ \\
\hline Kelly 2006 [61] & 44 & $\begin{array}{l}\text { lapatinib } 750 \mathrm{mg} / \mathrm{day} \\
\text { stopped at } 14 \text { weeks }\end{array}$ & $-0-11$ & 36 & metastatic & none & 2,600 & $\begin{array}{l}\text { female; no sequelae; } \\
\text { status APGAR 8/9/- }\end{array}$ \\
\hline Bader 2007 [62] & 38 & $\begin{array}{l}\text { paclitaxel } 175 \mathrm{mg} / \mathrm{m}^{2} \text {, } \\
\text { trastuzumab; stopped } \\
\text { after } 2 \text { cycles }\end{array}$ & $25^{+6}-26$ ( 2 cycles $)$ & $32+1 /$ caesarean & $\begin{array}{l}\text { metastatic spinal } \\
\text { cord compression }\end{array}$ & $\begin{array}{l}\text { oligo-anhydramnios; } \\
\text { fetal growth } \\
\text { retardation; fetal } \\
\text { renal failure } \\
\text { at } 31+6 \text { weeks }\end{array}$ & 1,460 & $\begin{array}{l}\text { male; bacterial } \\
\text { sepsis; hypotension; } \\
\text { transient renal and } \\
\text { respiratory failure }\end{array}$ \\
\hline Sekar 2007 [63] & 28 & $\begin{array}{l}3 \text { docetaxel } 190 \mathrm{mg} \\
+ \text { trastuzumab } \\
2 \text { cycles }\end{array}$ & $23-30$ & $\begin{array}{l}36+2 \text { week/ } \\
\text { elective } \\
\text { caesarean }\end{array}$ & $\begin{array}{l}\text { lung metastases } \\
\text { (20th week) }\end{array}$ & $\begin{array}{l}\text { anhydramnios at } \\
\text { 30th week; } \\
\text { reversible } \\
\text { fetal growth } \\
\text { restriction } \\
\text { (5th percentile) }\end{array}$ & 2,230 & $\begin{array}{l}\text { male; no sequelae; } \\
\text { status APGAR 7/9/5 }\end{array}$ \\
\hline Shrim 2007 [64] & 32 & $\begin{array}{l}\text { trastuzumab } 400 \mathrm{mg} \text {, } \\
3 \text { weekly; stopped } \\
\text { at } 24 \text { weeks }\end{array}$ & $0-24$ & $\begin{array}{l}\text { 37/elective } \\
\text { caesarean }\end{array}$ & $\begin{array}{l}\text { breast carcinoma, } \\
\text { metastatic }\end{array}$ & $\begin{array}{l}\text { reversible maternal } \\
\text { heart failure, } \\
\text { resolved slowly after } \\
\text { discontinuation of } \\
\text { trastuzumab }\end{array}$ & 2,600 & $\begin{array}{l}\text { female; } \\
\text { APGAR } \\
\text { 9/10/NRD }\end{array}$ \\
\hline Witzel 2007 [65] & 29 & $\begin{array}{l}\text { 1st line: } 24 \text { cycles } \\
\text { vinorelbine } 25 \mathrm{mg} / \mathrm{m}^{2} \\
+ \text { trastuzumab } \\
2 \mathrm{mg} / \mathrm{kg} \text { weekly, } \\
\text { trastuzumab } \\
6 \mathrm{mg} / \mathrm{kg} 3 \text {-weekly } \\
25 \mathrm{cycles} ; \\
\text { total dose } 56 \mathrm{mg} / \mathrm{kg}\end{array}$ & $\begin{array}{l}0-25,23 \text { th week } \\
\text { pregnancy } \\
\text { diagnosis }\end{array}$ & 27/caesarean & $\begin{array}{l}\text { invasive ductal, } \\
\text { lung metastases, } \\
\text { cerebral } \\
\text { metastases } \\
\text { under } \\
\text { trastuzumab } \\
\text { alone }\end{array}$ & $\begin{array}{l}\text { oligohydramnios; } \\
\text { vaginal bleeding }\end{array}$ & 1,015 & $\begin{array}{l}\text { female; } \\
\text { APGAR 8/7/6; } \\
\text { pH = } 7.48 \text { umbil. } \\
\text { artery; respiratory } \\
\text { failure }\end{array}$ \\
\hline
\end{tabular}

nancy. Ondansetron has the longest safety record, and no increased frequency of untoward effects has been reported in connection with treating pregnant patients [57]. Tropisetron, an antimetic in frequent use in Europe, has been classified as a class $\mathrm{C}$ drug based on malformations observed following in utero exposure in laboratory rodents; in our view, there is no use for tropisetron in pregnancy. Granisetron and palonosetron have rarely been used in pregnancy. There are no reports on aprepitant, the novel neurokinin-1 receptor agonist in pregnant patients. Granulocyte colony stimulating factor (G-CSF, e.g. filgrastim) is known to cross the placenta and has been used occasionally in pregnant patients; there are only few reports about the use of filgrastim in pregnancy. Filgrastim and pegfilgrastim are category $\mathrm{C}$ drugs due to the induction of abortion and malformations in rodents. Erythropoietin and darbepoietin have been used in a small number of pregnant patients undergoing dialysis treatment for renal failure. So far, no malformations could be attributed to the use of erythropoietins. Both drugs belong to the pregnancy category C. In the context of cancer chemotherapy, transfusions may be preferable to the use of erythropoietins [58].

\section{Conclusion}

In the treatment of the pregnant breast cancer patient, the evidence upon which we base our decisions has been largely limited to case reports, case control studies, and retrospective cohorts. The German Breast group launched a prospective and retrospective registry for women with breast cancer during pregnancy. So far, 142 patients with the diagnosis of breast cancer during pregnancy have been prospectively and retrospectively collected (Loibl et al., European Breast Cancer Conference, 2008). All women with a diagnosis of breast cancer during pregnancy can be registered independently of the applied therapy. Further information is available under www.germanbreastgroup.de/pregnancy. 


\section{References}

1 Ahn BY, Kim HH, Moon WK, Pisano ED, Kim HS, Cha ES, Kim JS, Oh KK, Park SH: Pregnancy- and lactation-associated breast cancer: mammographic and sonographic findings. J Ultrasound Med 2003; 22:491-497.

2 Liberman L, Giess CS, Dershaw DD, Deutch BM, Petrek JA: Imaging of pregnancy-associated breast cancer. Radiology 1994;191:245-248.

3 Mazonakis M, Varveris H, Damilakis J, Theoharopoulos N, Gourtsoyiannis N: Radiation dose to conceptus resulting from tangential breast irradiation. Int J Radiat Oncol Biol Phys 2003;55:386-391.

$\checkmark 4$ Ebert U, Loffler H, Kirch W: Cytotoxic therapy and pregnancy. Pharmacol Ther 1997;74:207-220.

5 Gentilini O, Cremonesi M, Trifiro G, Ferrari M, Baio SM, Caracciolo M, Rossi A, Smeets A, Galimberti V, Luini A, Tosi G, Paganelli G: Safety of sentinel node biopsy in pregnant patients with breast cancer. Ann Oncol 2004;15:1348-1351.

6 Bonnier P, Romain S, Dilhuydy JM, Bonichon F, Julien JP, Charpin C, Lejeune C, Martin PM, Piana $\mathrm{L}$ : Influence of pregnancy on the outcome of breast cancer: a case-control study. Societe Francaise de Senologie et de Pathologie Mammaire Study Group. Int J Cancer 1997;72:720-727.

7 Gentilini O, Cremonesi M, Trifiro G, Ferrari M, Baio SM, Caracciolo M, Rossi A, Smeets A, Galimberti V, Luini A, Tosi G, Paganelli G: Safety of sentinel node biopsy in pregnant patients with breast cancer. Ann Oncol 2004;15:1348-1351.

$>8$ Middleton LP, Amin M, Gwyn K, Theriault R, Sahin A: Breast carcinoma in pregnant women: assessment of clinicopathologic and immunohistochemical features. Cancer 2003;98:1055-1060.

$\checkmark 9$ Miller KD, Chap LI, Holmes FA, Cobleigh MA, Marcom PK, Fehrenbacher L, Dickler M, Overmoyer BA, Reimann JD, Sing AP, Langmuir V, Rugo HS: Randomized phase III trial of capecitabine compared with bevacizumab plus capecitabine in patients with previously treated metastatic breast cancer. J Clin Oncol 2005;23: 792-799.

10 Reed W, Hannisdal E, Skovlund E, Thoresen S, Lilleng P, Nesland JM: Pregnancy and breast cancer: a population-based study. Virchows Arch 2003; 443:44-50.

11 Ring AE, Smith IE, Jones A, Shannon C, Galani E, Ellis PA: Chemotherapy for breast cancer during pregnancy: an 18-year experience from five London teaching hospitals. J Clin Oncol 2005;23:4192-4197.

12 Woo JC, Yu T, Hurd TC: Breast cancer in pregnancy: a literature review. Arch Surg 2003;138: 91-98.

13 Aziz S, Pervez S, Khan S, Siddiqui T, Kayani N, Israr M, Rahbar M: Case control study of novel prognostic markers and disease outcome in pregnancy/lactation-associated breast carcinoma. Pathol Res Pract 2003;199:15-21.

-14 Colleoni M, Rotmensz N, Robertson C, Orlando L, Viale G, Renne G, Luini A, Veronesi P, Intra M, Orecchia R, Catalano G, Galimberti V, Nole F, Martinelli G, Goldhirsch A: Very young women ( $<35$ years) with operable breast cancer: features of disease at presentation. Ann Oncol 2002;13: 273-279.

15 Middleton LP, Amin M, Gwyn K, Theriault R, Sahin A: Breast carcinoma in pregnant women: assessment of clinicopathologic and immunohistochemical features. Cancer 2003;98:1055-1060.

16 Barthelmes L, Davidson LA, Gaffney C, Gateley CA: Pregnancy and breast cancer. BMJ 2005;330: 1375-1378.
Duncan PG, Pope WD, Cohen MM, Greer N: Fetal risk of anesthesia and surgery during pregnancy. Anesthesiology 1986;64:790-794.

18 Mazze RI, Kallen B: Reproductive outcome after anesthesia and operation during pregnancy: a registry study of 5405 cases. Am J Obstet Gynecol 1989;161:1178-1185.

19 Kaufmann M, von MG, Smith R, Valero V, Gianni L, Eiermann W, Howell A, Costa SD, Beuzeboc P, Untch M, Blohmer JU, Sinn HP, Sittek R, Souchon R, Tulusan AH, Volm T, Senn HJ: International expert panel on the use of primary (preoperative) systemic treatment of operable breast cancer: review and recommendations. J Clin Oncol 2003; 21:2600-2608.

20 Kuerer HM, Gwyn K, Ames FC, Theriault RL: Conservative surgery and chemotherapy for breast carcinoma during pregnancy. Surgery 2002;131: 108-110.

21 Berry DL, Theriault RL, Holmes FA, Parisi VM, Booser DJ, Singletary SE, Buzdar AU, Hortobagyi GN: Management of breast cancer during pregnancy using a standardized protocol. J Clin Oncol 1999;17:855-861.

22 Gentilini O, Cremonesi M, Trifiro G, Ferrari M, Baio SM, Caracciolo M, Rossi A, Smeets A, Galimberti V, Luini A, Tosi G, Paganelli G: Safety of sentinel node biopsy in pregnant patients with breast cancer. Ann Oncol 2004;15:1348-1351.

23 Gentilini O, Cremonesi M, Trifiro G, Ferrari M, Baio SM, Caracciolo M, Rossi A, Smeets A, Galimberti V, Luini A, Tosi G, Paganelli G: Safety of sentinel node biopsy in pregnant patients with breast cancer. Ann Oncol 2004;15:1348-1351.

24 Mondi MM, Cuenca RE, Ollila DW, Stewart JH, Levine EA: Sentinel lymph node biopsy during pregnancy: initial clinical experience. Ann Surg Oncol 2007;14:218-221.

25 Albo D, Wayne JD, Hunt KK, Rahlfs TF, Singletary SE, Ames FC, Feig BW, Ross MI, Kuerer HM: Anaphylactic reactions to isosulfan blue dye during sentinel lymph node biopsy for breast cancer. Am J Surg 2001;182:393-398.

26 Crivellaro M, Senna G, Dama A, Bonadonna P, Passalacqua G: Anaphylaxis due to patent blue dye during lymphography, with negative skin prick test. J Investig Allergol Clin Immunol 2003;13:71-72.

27 Bradley B, Fleck A, Osei EK: Normalized data for the estimation of fetal radiation dose from radiotherapy of the breast. Br J Radiol 2006;79:818-827.

$28 \mathrm{Kal} \mathrm{HB}$, Struikmans H: Radiotherapy during pregnancy: fact and fiction. Lancet Oncol 2005;6: 328-333.

29 Hebert-Croteau N, Freeman CR, Latreille J, Rivard M, Brisson J: A population-based study of the impact of delaying radiotherapy after conservative surgery for breast cancer. Breast Cancer Res Treat 2004;88:187-196.

30 Hershman DL, Wang X, McBride R, Jacobson JS, Grann VR, Neugut AI: Delay in initiating adjuvant radiotherapy following breast conservation surgery and its impact on survival. Int J Radiat Oncol Biol Phys 2006;65:1353-1360.

31 Vujovic O, Cherian A, Yu E, Dar AR, Stitt L, Perera F: The effect of timing of radiotherapy after breast-conserving surgery in patients with positive or close resection margins, young age, and nodenegative disease, with long term follow-up. Int $\mathrm{J}$ Radiat Oncol Biol Phys 2006;66:687-690.
2 Kaufmann M, Hortobagyi GN, Goldhirsch A, Scholl S, Makris A, Valagussa P, Blohmer JU, Eiermann W, Jackesz R, Jonat W, Lebeau A, Loibl S, Miller W, Seeber S, Semiglazov V, Smith R, Souchon R, Stearns V, Untch M, von Minckwitz G: Recommendations from an international expert panel on the use of neoadjuvant (primary) systemic treatment of operable breast cancer: an update. J Clin Oncol 2006;24:1940-1949.

33 Colleoni M, Bonetti M, Coates AS, CastiglioneGertsch M, Gelber RD, Price K, Rudenstam CM, Lindtner J, Collins J, Thurlimann B, Holmberg S, Veronesi A, Marini G, Goldhirsch A: Early start of adjuvant chemotherapy may improve treatment outcome for premenopausal breast cancer patients with tumors not expressing estrogen receptors. The International Breast Cancer Study Group. J Clin Oncol 2000;18:584-590.

34 Cardonick E, Iacobucci A: Use of chemotherapy during human pregnancy. Lancet Oncol 2004;5: 283-291.

35 Barthelmes L, Davidson LA, Gaffney C, Gateley CA: Pregnancy and breast cancer. BMJ 2005;330: 1375-1378.

36 Ring AE, Smith IE, Jones A, Shannon C, Galani E, Ellis PA: Chemotherapy for breast cancer during pregnancy: an 18-year experience from five London teaching hospitals. J Clin Oncol 2005;23:4192-4197.

37 Hahn KM, Johnson PH, Gordon N, Kuerer H, Middleton L, Ramirez M, Yang W, Perkins G, Hortobagyi GN, Theriault RL: Treatment of pregnant breast cancer patients and outcomes of children exposed to chemotherapy in utero. Cancer 2006;107:1219-1226.

38 Zemlickis D, Lishner M, Degendorfer P, Panzarella T, Burke B, Sutcliffe SB, Koren G: Maternal and fetal outcome after breast cancer in pregnancy. Am J Obstet Gynecol 1992;166:781-787.

39 Woo JC, Yu T, Hurd TC: Breast cancer in pregnancy: a literature review. Arch Surg 2003;138:91-98.

40 Henderson IC, Berry DA, Demetri GD, Cirrincione CT, Goldstein LJ, Martino S, Ingle JN, Cooper MR, Hayes DF, Tkaczuk KH, Fleming G, Holland JF Duggan DB, Carpenter JT, Frei E, III, Schilsky RL, Wood WC, Muss HB, Norton L: Improved outcomes from adding sequential paclitaxel but not from escalating Doxorubicin dose in an adjuvant chemotherapy regimen for patients with nodepositive primary breast cancer. J Clin Oncol 2003 . 21:976-983

41 Mamounas EP, Bryant J, Lembersky B, Fehrenbacher L, Sedlacek SM, Fisher B, Wickerham DL, Yothers G, Soran A, Wolmark N: Paclitaxel after doxorubicin plus cyclophosphamide as adjuvant chemotherapy for node-positive breast cancer: results from NSABP B-28. J Clin Oncol 2005;23: 3686-3696.

42 Martin M, Pienkowski T, Mackey J, Pawlicki M, Guastalla JP, Weaver C, Tomiak E, Al-Tweigeri T, Chap L, Juhos E, Guevin R, Howell A, Fornander T, Hainsworth J, Coleman R, Vinholes J, Modiano M, Pinter T, Tang SC, Colwell B, Prady C, Provencher L, Walde D, Rodriguez-Lescure A, Hugh J, Loret C, Rupin M, Blitz S, Jacobs P, Murawsky M, Riva A, Vogel C: Adjuvant docetaxel for node-positive breast cancer. N Engl J Med

2005;352:2302-2313.
43 De Santis M, Lucchese A, De CS, Ferrazani S, Caruso A: Metastatic breast cancer in pregnancy: first case of chemotherapy with docetaxel. Eur J Cancer Care (Engl) 2000;9:235-237. 
44 Gadducci A, Cosio S, Fanucchi A, Nardini V, Roncella M, Conte PF, Genazzani AR: Chemotherapy with epirubicin and paclitaxel for breast cancer during pregnancy: case report and review of the literature. Anticancer Res 2003;23:5225-5229.

45 Nieto Y, Santisteban M, Aramendia JM, Fernandez-Hidalgo $\mathrm{O}$, Garcia-Manero $\mathrm{M}$, Lopez $\mathrm{G}$ : Docetaxel administered during pregnancy for inflammatory breast carcinoma. Clin Breast Cancer 2006;6:533-534.

46 Potluri V, Lewis D, Burton GV: Chemotherapy with taxanes in breast cancer during pregnancy: case report and review of the literature. Clin Breast Cancer 2006;7:167-170.

47 Mir O, Berveiller P, Ropert S, Goffinet F, Pons G, Treluyer JM, Goldwasser F: Emerging therapeutic options for breast cancer chemotherapy during pregnancy. Ann Oncol 2007.

48 Arceci RJ, Croop JM, Horwitz SB, Housman D: The gene encoding multidrug resistance is induced and expressed at high levels during pregnancy in the secretory epithelium of the uterus. Proc Natl Acad Sci U S A 1988;85:4350-4354.

49 Smit JW, Huisman MT, van TO, Wiltshire HR, Schinkel AH: Absence or pharmacological blocking of placental P-glycoprotein profoundly increases fetal drug exposure. J Clin Invest 1999;104:1441-1447.

50 Romond EH, Perez EA, Bryant J, Suman VJ, Geyer CE Jr, Davidson NE, Tan-Chiu E, Martino S, Paik S, Kaufman PA, Swain SM, Pisansky TM, Fehrenbacher L, Kutteh LA, Vogel VG, Visscher DW, Yothers G, Jenkins RB, Brown AM, Dakhil SR, Mamounas EP, Lingle WL, Klein PM, Ingle JN, Wolmark N: Trastuzumab plus adjuvant chemotherapy for operable HER2-positive breast cancer. N Engl J Med 2005;353:1673-1684.
51 Slamon DJ, Eiermann W, Robert N, et al.: Phase III trial comparing AC-T with AC-TH and with $\mathrm{TCH}$ in the adjuvant treatment of Her2 positive early breast cancer patients: first interim efficacy analysis. Breast Cancer Res Treat 2005;89(Suppl 1):abstr 5.

52 Piccart-Gebhart MJ, Procter M, Leyland-Jones B, Goldhirsch A, Untch M, Smith I, Gianni L, Baselga J, Bell R, Jackisch C, Cameron D, Dowsett M, Barrios CH, Steger G, Huang CS, Andersson M, Inbar M, Lichinitser M, Lang I, Nitz U, Iwata H, Thomssen C, Lohrisch C, Suter TM, Ruschoff J, Suto T, Greatorex V, Ward C, Straehle C, McFadden E, Dolci MS, Gelber RD: Trastuzumab after adjuvant chemotherapy in HER2-positive breast cancer. N Engl J Med 2005;353:1659-1672.

53 Waterston AM, Graham J: Effect of adjuvant trastuzumab on pregnancy. J Clin Oncol 2006;24: 321-322.

54 Fanale MA, Uyei AR, Theriault RL, Adam K, Thompson RA: Treatment of metastatic breast cancer with trastuzumab and vinorelbine during pregnancy. Clin Breast Cancer 2005;6:354-356.

55 Watson WJ: Herceptin (trastuzumab) therapy during pregnancy: association with reversible anhydramnios. Obstet Gynecol 2005;105:642-643.

56 Kelly H, Graham M, Humes E, Dorflinger LJ, Boggess KA, O’Neil BH, Harris J, Spector NL, Dees EC: Delivery of a healthy baby after firsttrimester maternal exposure to lapatinib. Clin Breast Cancer 2006;7:339-341.

57 Einarson A, Maltepe C, Navioz Y, Kennedy D, Tan MP, Koren G: The safety of ondansetron for nausea and vomiting of pregnancy: a prospective comparative study. BJOG 2004;111:940-943.
58 Aebi S, Loibl S: Breast cancer during pregnancy: medical therapy and prognosis. Recent Results Cancer Res 2008;178:45-55.

59 Watson WJ: Herceptin (trastuzumab) therapy during pregnancy: association with reversible anhydramnios. Obstet Gynecol 2005;105:642-643.

60 Waterston AM, Graham J: Effect of adjuvant trastuzumab on pregnancy. J Clin Oncol 2006;24: 321-322.

61 Kelly H, Graham M, Humes E, Dorflinger LJ, Boggess KA, O'Neil BH, Harris J, Spector NL, Dees EC: Delivery of a healthy baby after firsttrimester maternal exposure to lapatinib. Clin Breast Cancer 2006;7:339-341.

62 Bader AA, Schlembach D, Tamussino KF, Pristauz G, Petru E: Anhydramnios associated with administration of trastuzumab and paclitaxel for metastatic breast cancer during pregnancy. Lancet Oncol 2007; 8:79-81.

63 Sekar R, Stone PR: Trastuzumab use for metastatic breast cancer in pregnancy. Obstet Gynecol 2007; 110:507-510.

64 Shrim A, Garcia-Bournissen F, Maxwell C, Farine D, Koren G: Favorable pregnancy outcome following Trastuzumab (Herceptin) use during pregnancy - case report and updated literature review. Reprod Toxicol 2007;23:611-613.

65 Witzel ID, Muller V, Harps E, Janicke F, Dewit M: Trastuzumab in pregnancy associated with poor fetal outcome. Ann Oncol 2008;19:191-192. 